\title{
Korelasi Bobot Potong terhadap Produksi Karkas Ternak Sapi Bali di RPH Kota Kefamenanu
}

\author{
Martinus Neno ${ }^{\mathrm{a}}$ \\ ${ }^{a}$ Fakultas Pertanian, Universitas Timor, Kefamenanu, TTU - NTT, Indonesia.
}

\section{Article Info}

\section{Article history:}

Received 18 September 2018

Received in revised form 12 Oktober 2018

Accepted 14 Oktober 2018

\section{DOI:}

https://doi.org/10.32938/ja.v3i4.545

\section{Keywords:}

Sapi Bali

Bobot potong

Korelasi

Berat \& Persentase Karkas

\section{Abstrak}

Penelitian ini telah dilaksanakan di RPH Kota Kefamenanu Kabupaten Timor Tengah Utara selama 2 bulan dan tujuan dari penelitian in adalah untuk mengetahui hubungan bobot potong terhadap produksi karkas Sapi Bali yang dipotong di RPH Kota Kefamenanu. Metode yang digunakan adalah metode eksperimen dengan melakukan pengukuran langsung ternak sapi yang dipotong di RPH Kota Kefamenanu. Variabel yang diukur meliputi bobot potong, berat karkas, persentase karkas, dan berat non karkas. Untuk mengetahui hubungan antar variabel, data dianalisis dengan menggunakan analisis korelasi. Hasil penelitian ini menunjukkan rata-rata bobot potong Sapi Bali pada kisaran bobot badan 150-199 kg adalah $177,86 \mathrm{~kg}$, berat karkas $78,76 \mathrm{~kg}$, persentase karkas 44,28\%, berat non karkas $99,10 \mathrm{~kg}$, dan persentase non karkas $55,71 \%$. Nilai korelasi bobot potong dengan berat karkas pada kisaran bobot badan 150-199 kg adalah sebesar 0,527 $(0,000)$; bobot potong dan berat non karkas sebesar 0,088 (0,580); bobot potong dan persentase karkas sebesar 0,327 (0,034); dan bobot potong dan persentase non karkas sebesar $0,204(0,194)$. Rata-rata bobot potong sapi bali betina kisaran bobot badan 200-250 kg adalah sebesar 226,29, berat karkas $115,10 \mathrm{~kg}$, persentase karkas 50,86 \%, berat non karkas $111,91 \mathrm{~kg}$, dan persentase non karkas 49,13\%. Nilai korelasi bobot potong dan berat karkas pada kisaran bobot badan 200-250 adalah sebesar 0,527 (0,000); bobot potong dan berat non karkas sebesar 0,088 (0,580); bobot potong dan persentase karkas sebesar 0,327 (0,034); dan bobot potong dan persentase non karkas sebesar $0,204(0,194)$. Dapat disimpulkan bahwa Sapi Bali dengan bobot potong 150-199 kg memiliki hubungan yang signifikan antara bobot potong dengan berat karkas dan non karkas; sebaliknya, ternak bobot badan 200-250 kg menunjukkan korelasi positif antara bobot potong dengan berat dan persentase karkas. Semakin tinggi bobot potong Sapi Bali semakin meningkat pula produksi karkasnya.

\section{Pendahuluan}

Kebutuhan permintaan daging secara nasional terus meningkat seiring dengan laju pertumbuhan ekonomi yang semakin baik, pembangunan pendidikan yang lebih maju, kesadaran kebutuhan nutrisi asal ternak semakin meningkat. Kondisi ini menyebabkan pemotongan sapi dari berbagai bangsa juga semakin meningkat untuk memenuhi kebutuhan daging (Suswono, 2009). Berdasarkan Data BPS Perkembangan produksi daging sapi di Indonesia pada periode tahun 2016 secara umum meningkat 2,61 kg/kapita/tahun. Hal ini disebabkan naiknya pendapatan masyarakat Indonesia. Konsumsi daging pada tahun 2016 adalah 750,000 ton (BPS, 2016). Sapi Bali merupakan sapi asli Indonesia, yang berpotensi besar dalam menghasilkan daging secara maksimal. Menurut Hafid (2005), Sapi Bali merupakan komoditi unggulan sebagai pemasok kebutuhan protein hewani yang baik. Ditinjau dari karakteristik karkas dan bentuk badan yang kompak dan serasi, Sapi Bali digolongkan sebagai sapi pedaging ideal, bahkan nilai mutu dagingnya lebih bermutu daripada sapi pedaging Eropa sepert Hereford dan Shortorn. Selain itu, Sapi Bali mempunyai keunggulan bertahan hidup pada lingkungan yang kurang memadai misalnya tanpa dikandangkan (tahan panas dan tahan hujan), dan tempat yang rendah kualitas pakannya walaupun ada penurunan produksi dan reproduksi.

Secara umum usaha sapi potong di Nusa Tenggara Timur, khususnya Kabupaten Timor Tengah Utara dilakukan secara turun-temurun dan dilakukan secara tradisional. Selain itu, orientasi usaha ternak ke arah ekonomis juga masih kurang, karena produk yang dihasilkan hanya untuk memenuhi kebutuhan hidup keluarga, juga sebagai saving untuk memenuhi kebutuhan lain yang sifatnya mendesak. Akibatnya ternak siap potong yang dihasilkan juga terbatas untuk memenuhi kebutuhan pasar.

Untuk menghasilkan daging yang maksimal, pertumbuhan ternak mempunyai arti penting sehingga perlu diperhatikan oleh peternak. Bila pertumbuhan ternak semakin tinggi, maka bobot akhir juga akan semakin tinggi pula sehingga karkas yang dihasilkan optimal. Pola pemeliharaan ternak yang semakin baik merupakan faktor yang berpengaruh terhadap pertumbuhan ternak seperti di atas. Di peternakan rakyat, peningkatan pertumbuhan ternak yang maksimal karena sebagian besar ternak dipelihara secara tradisional. Menurut Sampurna \& Suatha, (2010), kualitas produksi daging Sapi Bali tergantung pada pertumbuhannya karena produksi yang tinggi dapat dicapai dengan pertumbuhan yang cepat.

Bobot potong dan bobot karkas merupakan suatu indikator produktivitas ternak yang sangat penting dan tidak dapat dipisahkan satu dengan yang lainya karena keduanya saling berhubungan, bobot potong semakin meningkat maka produksi karkas pun meningkat (Soeparno, 2005). Meskipun memiliki pengaruh yang sangat penting dalam menentukan produksi karkas, pemotongan ternak belum sepenuhnya memperhatikan bobot potong.

\section{Metode}

Penelitian telah dilaksanakan di RPH Kota Kefamenanu Kabupaten Timo Tengah Utara selama 2 bulan yakni bulan Desember 2017 - Januari 2018 Peralatan yang digunakan adalah timbangan digital merek sonic scale A12E kapasitas $2000 \mathrm{~kg}$ dengan tingkat ketelitian $0,5 \mathrm{~kg}$ untuk menimbang berat potong dan timbangan gantung merek gajah dengan kapasitas $50 \mathrm{~kg}$ dengan tingkat ketelitian 200 gram untuk berat karkas, dan pita ukur untuk mengukur panjang karkas, lebar karkas dan kamera yang berfungsi untuk dokumentasi selama penelitian, serta alat tulis. Metode yang digunakan dalam penelitian ini adalah metode eksperimen pengukuran langsung yaitu berdasarkan jumlah ternak per hari yang dipotong di RPH Kota Kefamenanu. Variabel yang diukur yakni korelasi bobot potong dengan bobot karkas, korelasi bobot potong dengan berat karkas, korelasi bobot potong dengan lebar karkas dan korelasi bobot potong dengan panjang karkas.
Prosedur kerja yang ditempuh dalam penelitian ini adalah sebagai berikut: a. Bobot potong ditimbang menggunakan timbangan digital merek sonic scale A12E kapasitas $2000 \mathrm{~kg}$ dengan tingkat ketelitian $0,5 \mathrm{~kg}$. Menyiapkan ternak dan timbangan sesuai dengan prosedur, kemudian sapi dimasukkan ke dalam kandang yang sudah tersedia timbangan. Nilai yang tertera pada monitor merupakan bobot potong sapi tersebut.

b. Berat karkas ditimbang menggunakan timbangan gantung merek gajah kapasitas $50 \mathrm{~kg}$ dengan tingkat ketelitian 200 gram dan untuk mendapatkan berat non karkas diperoleh dari berat potong dikurang berat karkas untuk memperoleh berat non karkas.

c. Lebar karkas diukur menggunakan pita ukur dari titik tertinggi gumba secara vertikal ke tanah sejajar bagian tepi bawah tulang dada.

d. Panjang karkas diukur menggunakan pita ukur dari ujung samping tulang bahu sampai dengan ujung tulang duduk.

Data yang diperoleh dianalisis secara deskriptif dengan cara menggunakan analisis statistik untuk menghitung rata-rata, standar deviasi sesuai Sugiyono (2000). Untuk mengetahui hubungan bobot potong, berat karkas, berat non karkas dan persentase karkas ternak Sapi Bali digunakan metode korelasi pearson.

\section{Hasil dan Pembahasan}

\subsection{Gambaran Umum Penelitian}

Rumah Pemotongan Hewan (RPH) Kota Kefamenanu sebagai salah satu RPH yang ada di TTU, yang didirikan pada tahun 1975 dengan luas $180 \mathrm{~m}^{2}$ dan dikategorikan sebagai RPH tipe I. Secara geografis RPH Kefamenanu terletak di Kelurahan Kefamenanu Selatan, sebelah Timur berbatasan dengan RT. 02 Kota Baru, sebelah Barat berbatasan dengan Jalan Eltari, sebelah Utara berbatasan dengan RT. 03 Kota Baru, sebelah Selatan berbatasan dengan sungai Dalehi.

Pemotongan hewan di RPH Kota Kefamenanu dilakukan setiap hari dengan waktu pemotongan dimulai antara jam 03.00-06.30 Wita. Proses pemotongan yang diterapkan pada RPH ini adalah sistem pemotongan tradisiona yang dilakukan dengan merebahkan sapi menggunakan tali tambang, kepala diletakan di atas lantai dan dihadapkan arah timur untuk menjaga kehalalan pemotongan sapi karena konsumen pada umumnya beragama Islam. Leher dipotong dengan pisau potong yang tajam pada rahang bawah sehingga oesophagus, Vena jugularis, Arteri carotis dan trachea dapat terpotong dengan sempurna sehingga mendapatkan pendarahan yang sempurna pula.

Sapi yang dipotong sebanyak 84 ekor masing-masing berat potong 150 $199 \mathrm{~kg} 42$ ekor dan 200-250 kg 42 ekor. Sapi yang disembelih di RPH Kota Kefamenanu adalah milik pengusaha. Jumlah sapi yang akan dipotong di RPH rata-rata 5-10 ekor setiap hari atau antara 100-300 kg daging sesuai permintaan pengusaha dan permintaan pasar. Pengadaan ternak Sapi Bali untuk kebutuhan daging pada Rumah Potong Hewan Kabupaten TTU dibeli dari para pedagang pengumpul yang ada di Kota Kefamenanu, ada juga yang langsung diperoleh dari para peternak. Pada umumnya ternak-ternak Sapi Bali tersebut berasal dari berbagai kecamatan dalam wilayah Kabupaten Timor Tengah Utara Berdasarkan hasil wawancara, kebanyakan sapi dibeli di daerah Insana dan Bikomi karena memiliki bobot potong yang baik dan harganya relatif murah Pemeliharaan ternak Sapi Bali yang baru dibeli baik dari petani maupun pedagang dilakukan dengan cara ditampung dan diikat kemudian diberikan hijauan secukupnya agar bobot potong ternak tidak menurun. Ternak sapi yang dipotong di RPH dalam kondisi sehat dengan terlebih dahulu ditimbang untuk mengetahui bobot potong. Fakta di lapangan yang terjadi selama ini pihak rumah potong hewan RPH mengabaikan penimbangan ternak sebelum dipotong sehingga tidak diketahui secara pasti bobot potong ternak yang baik. 
3.2. Rata-Rata Bobot Potong Sapi Bali dan Bobot Karkas.

Bobot potong Sapi Bali pada penelitian ini dikelompokkan berdasarkan sampel yang dibutuhkan yaitu Sapi Bali dengan bobot potong 150-199 kg dan 200-250 kg. Rata-rata bobot potong Sapi Bali di RPH Kota Kefamenanu dapat dilihat pada Tabel 1 .

Tabel 1. Rata-Rata Bobot Potong 150-199 kg.

\begin{tabular}{lccccc}
\hline $\begin{array}{l}\text { Jenis } \\
\text { Data }\end{array}$ & $\begin{array}{c}\text { Bobot Potong } \\
(\mathrm{Kg})\end{array}$ & $\begin{array}{c}\text { Berat } \\
\text { Karkas } \\
(\mathrm{Kg})\end{array}$ & $\begin{array}{c}\text { Persentase } \\
\text { Karkas } \\
(\%)\end{array}$ & $\begin{array}{c}\text { Berat Non } \\
\text { Karkas }(\mathrm{Kg})\end{array}$ & $\begin{array}{c}\text { Persentase } \\
\text { Non Karkas } \\
(\%)\end{array}$ \\
\hline Rata-rata & 177,86 & 78,76 & 44,28 & 99,10 & 55,71 \\
\hline SD & 14,50 & 10,92 & 5,07 & 11,68 & 4,42 \\
\hline
\end{tabular}

Bobot potong adalah bobot ternak sesaat sebelum ternak disembelih yang berpengaruh terhadap bobot karkas. Setiap kenaikan bobot potong akan diikuti dengan kenaikan persentase karkas (Pratama $d k k ., 2015)$. Hasil penelitian pada Tabel 1. menunjukkan bahwa rata-rata bobot potong Sapi Bali yang dipotong di $\mathrm{RPH}$ adalah $177,86 \pm 14,50 \mathrm{~kg}$, berat karkas $78,76 \mathrm{~kg} \pm 10,92$, dan persentase karkas $44,28 \pm 5,07$. Berat non karkas rata-rata 99,10 $\pm 11,68$ dan persentase non karkas dengan nilai rata-rata 55,71 \% $\pm 4,42$. Faktor yang menyebabkan berat karkas menurun sedangkan berat non karkas meningkat dikarenakan pakan, dan pola pemeliharaan dan persentase karkas rendah karena tidak dapat dipuasakan.

Pada umumnya sistem pemeliharaan Sapi Bali adalah sistem ekstensif tradisional dimana ternak dilepas di padang penggembalaan, secara terusmenerus dan pakan yang dikonsumsi bervariasi. Sistem pemeliharaan juga sangat menentukan keberhasilan produksi sapi potong, namun apabila lingkungan tidak mendukung kemampuan genetik seekor ternak, maka produksinya juga akan rendah sedangkan faktor lingkungan merupakan faktor pendukung bagi kelangsungan hidup ternak serta produksinya. Jika dibandingkan dengan penelitian terdahulu Ninu (2008) menyatakan bahwa rata-rata bobot karkas 89,24 dengan standar deviasi 15,37.

Hasil penelitian ini menunjukkan bahwa pemuasaan sapi belum menyebabkan terjadinya penurunan persentase karkas. Namun, persentase karkas sapi yang dipuasakan lebih tinggi daripada persentase karkas sapi yang tidak dipuasakan. Hal ini terjadi karena sapi yang tidak dipuasakan tidak mengalami penyusutan bobot hidup sehingga persentase karkas yang dihasilkan lebih rendah. Perbedaan dari kedua penelitian ini diduga karena sapi yang dipotong rata-rata skor kondisi tubuhnya gemuk, sedangkan pada penelitian ini di bahwa rata-rata karena ternak sapi yang di potong rata-rata 3,83\% skor kondisinya kurus $2,00 \%$ Sedang 3,00\% dan gemuk 4,00\%. Manurung (2008) menyatakan laju pertambahan bobot potong dipengaruhi oleh umur, lingkungan dan genetik di mana bobot badan awal fase penggemukan berhubungan dengan bobot badan dewasa. Pola pertumbuhan ternak tergantung pada sistem manajemen yang dipakai, tingkat nutrisi yang tersedia, kesehatan dan iklim. Pengaruh jenis kelamin pada semua jenis hewan terkadang berlangsung cepat, lambat dan bahkan terhenti jauh sebelum hewan tersebut mencapai ukuran besa tubuh karena dapat dipengaruhi oleh faktor genetis ataupun lingkungan. Untuk rata-rata bobot potong 200-250 kg Sapi Bali yang dipotong pada RPH Kota Kefamenanu dapat dilihat pada Tabel 2.

Tabel 2. Rata-Rata Bobot Potong 200-250 kg Sapi Bali.

\begin{tabular}{lccccc} 
Jenis Data & $\begin{array}{c}\text { Bobot } \\
\text { Potong } \\
(\mathrm{Kg})\end{array}$ & $\begin{array}{c}\text { Berat } \\
\text { Karkas } \\
(\mathrm{Kg})\end{array}$ & $\begin{array}{c}\text { Persentase } \\
\text { Karkas }(\%)\end{array}$ & $\begin{array}{c}\text { Berat Non } \\
\text { Karkas } \\
(\mathrm{Kg})\end{array}$ & $\begin{array}{c}\text { Persentase } \\
\text { Non Karkas } \\
(\mathrm{Kg})\end{array}$ \\
\hline Rata-rata & 226,29 & 115,10 & 50,86 & 111,19 & 49,13 \\
\hline SD & 15,68 & 10,25 & 4,19 & 17,68 & 6,59 \\
\hline
\end{tabular}

Hasil penelitian pada Tabel 2. menunjukkan bahwa rata-rata bobot potong Sapi Bali yang dipotong di RPH Kefamenanu adalah 200-250 kg memiliki bobot potong rata-rata $226,29 \pm 15,68$ berat karkas $115,10 \pm 10,25$, dan persentase karkas $50,87 \pm 4,19$. Berat non karkas rata-rata $111,19 \pm 17,68$ dan persentase non karkas rata-rata $49,13 \pm 6,59$. Faktor yang menyebabkan berat karkas meningkat sedangkan berat non karkas menurun dikarenakan pakan, pola pemeliharaan dan bangsa. Pada umumnya sistem pemeliharaan sapi Bali adalah sistem ekstensif tradisional di mana ternak dilepas di padang penggembalaan, secara terusmenerus dan pakan yang dikonsumsi bervariasi. Sistem pemeliharaan juga sangat menentukan keberhasilan produksi sapi potong, namun apabila lingkungan tidak mendukung kemampuan genetik seekor ternak, maka produksinya juga akan rendah sedangkan faktor lingkungan merupakan faktor pendukung bagi kelangsungan hidup ternak serta produksinya. Jika dibandingkan dengan penelitian terdahulu Ninu (2008) menyatakan bahwa rata-rata 114,87 $\pm 11,53$ dan persentase sebesar 53,26\%. Hasil penelitian pada Tabel 1. dan Tabel 2. menunjukkan bahwa bobot potong sangat menentukan berat potong terhadap produksi karkas. Semakin tinggi berat potong, berat karkas, persentase karkas yang dihasilkan semakin tinggi pula. Sehingga terdapat perbedaan bobot potong ternak Sapi Bali, di mana pada berat potong antara 200-250 kg memiliki berat potong yang lebih baik dibandingkan dengan berat potong antara 150-199. Perbedaan bobot karkas Sapi Bali disebabkan perbedaan ukuran skor kondisi tubuh oleh faktor umur, pakan, lingkungan, dan iklim di sekitar habitat ternak sapi juga karena faktor inbreeding. Ternak yang kekurangan pakan akan mempunyai bobot badan yang rendah karena intake pakan lebih banyak digunakan untuk hidup pokok bukan untuk dideposit menjadi daging.
Menurut Padang \& Irmawati ( 2007) semakin tinggi bobot potong maka akan semakin tinggi juga bobot karkas yang dihasilkan. Jumlah dan mutu pakan yang baik tidak dapat merubah tubuh hewan yang secara genetis bertubuh kecil, tetapi pemberian pakan dalam jumlah yang rendah tidak akan mampu memberikan pertambahan bobot hidup dan pertumbuhan karkas secara optimal sesuai dengan potensi genetik yang ada pada masing-masing hewan. Kecepatan tumbuh, persentase karkas yang tinggi hanya mungkin dapat terealisasi apabila hewan tersebut dapat memperoleh pakan yang cukup dan faktor bangsa mempunyai pengaruh terhadap persentase karkas. Soeparno (2005) menyatakan perbedaan komposisi tubuh dan karkas di antara bangsa ternak, terutama disebabkan oleh perbedaan ukuran tubuh atau perbedaan berat potong saat dewasa.

\subsection{Korelasi Antara Bobot Potong dengan Berat Karkas/Berat Non Karkas Sapi Bali pada RPH Kota Kefamenanu}

Kontribusi bobot potong ternak Sapi Bali terhadap kualitas produksi karkas dalam penelitian ini diukur melalui, berat karkas, berat non karkas, persentase karkas dan non karkas yang dilakukan melalui pengukuran langsung di lapangan. Hasil perhitungan korelasi bobot potong dengan berat karkas, berat non karkas, persentase karkas dan persentase non karkas Sapi Bali di RPH Kota Kefamenanu dapat dilihat pada Tabel 3.

Tabel 3. Korelasi Bobot Potong Sapi Bali dengan Rataan 150-199 Kg yang Dipotong di RPH Kota Kefamenanu.

\begin{tabular}{lcccc}
\hline \multicolumn{1}{c}{ Bobot Potong } & $\begin{array}{c}\text { Berat } \\
\text { Karkas }\end{array}$ & $\begin{array}{c}\text { Berat Non } \\
\text { Karkas }\end{array}$ & $\begin{array}{c}\text { Persentase } \\
\text { Karkas }\end{array}$ & $\begin{array}{c}\text { Persentase } \\
\text { Non Karkas }\end{array}$ \\
\hline Pearson Correlation & 0,459 & 0,725 & 0,327 & 0,046 \\
\hline Sig. (2-talled) & 0,002 & 0,000 & 0,114 & 0,773 \\
\hline $\mathrm{N}$ & 42 & 42 & 42 & 42 \\
\hline
\end{tabular}

Hasil penelitian korelasi bobot potong Sapi Bali betina pada rata-rata berat (150-199 kg) pada Tabel 3. menunjukkan sebaran angka korelasi yang berbeda yakni untuk berat karkas adalah $0,459(0,002)$; berat non karkas $0,725(0,000)$; persentase karkas adalah 0,338 $(0,114)$; dan persentase non karkas $0,046(0,773)$ Bilamana korelasi (r) mendekati 1 atau -1 , hubungan antara kedua variabel kuat, dan dikatakan terdapat korelasi yang tinggi. Sedangkan bila $\mathrm{r}$ mendekati nol, maka hubungan antara $\mathrm{X}$ dan $\mathrm{Y}$ lemah, atau mungkin tidak ada sama sekali (Imamul $d k k$., 2007). Berdasarkan pendapat Imamul $d k k$. (2007) maka nilai korelasi antara bobot potong dengan berat karkas atau berat non karkas Sapi Bali pada RPH Kota Kefamenanu pada penelitian ini hampir mendekati 1 sehingga dikatakan hubungan bobot potong dengan berat karkas atau berat non karkas memiliki korelasi yang tinggi.

Pradana $d k k$. (2014) yang memperoleh keterkaitan hubungan yang signifikan antara bobot potong dengan bobot karkas dengan nilai koefisien korelasi sebesar 0,995. Hal ini menunjukkan bahwa dengan bobot potong yang besar maka akan menghasilkan bobot karkas yang meningkat pula. Wiyatna (2007) menyatakan bahwa bobot potong yang tinggi selalu diikuti dengan tingginya bobot karkas. Sehingga dapat dikatakan bahwa perbedaan ukuran kerangka tubuh sapi potong dapat mempengaruhi karakteristik karkas yang dihasilkan. Perhitungan korelasi bobot potong dengan rataan berat 200-250 kg Sapi Bali yang dipotong di RPH Kota Kefamenanu dapat dilihat pada Tabel 4.

Tabel 4. Korelasi Bobot Potong Sapi Bali dengan Rataan 200-250 kg yang Dipotong di RPH Kota Kefamenanu.

\begin{tabular}{lcccc}
\hline \multicolumn{1}{c}{ Bobot Potong } & $\begin{array}{c}\text { Berat } \\
\text { Karkas }\end{array}$ & $\begin{array}{c}\text { Berat Non } \\
\text { Karkas }\end{array}$ & $\begin{array}{c}\text { Persentase } \\
\text { Karkas }\end{array}$ & $\begin{array}{c}\text { Persentase } \\
\text { Non Karkas }\end{array}$ \\
\hline Pearson Correlation & 0,57 & 0,08 & 0,338 & 0,204 \\
\hline Sig. (2-talled) & 0,00 & 0,50 & 0,034 & 0,194 \\
\hline $\mathrm{N}$ & 42 & 42 & 42 & 42 \\
\hline
\end{tabular}

Pada Tabel 4. terlihat bahwa hasil analisis korelasi bobot potong Sapi Bali rata-rata berat potong (200-250) kg menunjukkan sebaran angka korelasi yakni untuk berat karkas $0,527(0,000)$; berat non karkas $0,088(0,580)$; persentase karkas sebanyak $0,327(0,034)$; dan persentase non karkas sebanyak 0,204 $(0,194)$. Faktor yang mempengaruhi produksi non karkas antara lain bobot potong, bangsa, umur dan pakan. Hal ini sesuai dengan Lestari $d k k$. (2010) menyatakan bahwa produksi non karkas dipengaruhi oleh antara lain bobot potong, bangsa, umur dan pakan. Persentase karkas dan persentase non karkas merupakan hal penting dalam mengevaluasi produksi karkas ternak Sapi Bali.

Korelasi bobot potong Sapi Bali sebagaimana pada Tabel 3. dan Tabel 4 di atas menunjukkan bahwa ternak Sapi Bali dengan rataan bobot potong 200$250 \mathrm{~kg}$ memberi kontribusi terbaik terhadap berat karkas dengan nilai korelasi (r) $0,527(0,000)$. Hal ini menunjukkan bahwa semakin besar bobot potong akan semakin besar pula sumbangannya terhadap pembentukan bobot karkas. Tujuan akhir dari suatu peternakan sapi potong yang dihasilkannya karkas yang berkuantitas dan berkualitas tinggi sehingga daging yang dapat dikonsumsi atau dimakan pun tinggi (Pradana $d k k$., 2014). Korelasi bobot potong dengan berat non karkas Sapi Bali yang dipotong di RPH Kota Kefamenanu menunjukkan bahwa ternak Sapi Bali betina rataan bobot potong 200-250 kg menghasilkan berat non karkas lebih rendah dengan nilai korelasi (r) sebesar 0,088 $(0,580)$ Menurut Soeparno (2005), bobot potong yang semakin meningkat menghasilkan karkas yang semakin meningkat pula, sehingga dapat diharapkan bagian-bagian 
dari karkas menjadi lebih banyak. Adapun bagian-bagian non karkas Sapi Bali yang dipotong antara lain kepala, kulit, kaki, ekor, paru-paru, jantung, limpa, hati, usus, lambung. Hasil penelitian pada Tabel 2. menunjukkan bahwa ternak Sapi Bali dengan rataan bobot potong antara 200-250 kg memiliki persentase karkas dan persentase non karkas dengan bobot potong masing-masing dengan nilai korelasi adalah 0,338 (0,034); dan 0,204 $(0,194)$. Persentase karkas cenderung meningkat karena terhadap ukuran kerangka tubuh. Hal tersebut dikarenakan adanya perbedaan genetik antar bangsa tersebut sesuai dengan pernyataan Carvalho $d k k$. (2010) faktor yang mempengaruhi laju pertumbuhan dan perkembangan ternak antara lain pakan, jenis kelamin, hormon, genetik, lingkungan dan iklim.

Menurut Ismail $d k k$. (2014) di mana bobot potong yang tinggi akan menghasilkan produksi karkas yang tinggi pula. Dalam kaitannya dengan umur, pertambahan umur ternak yang sejalan dengan pertambahan bobot hidup maka bobot karkas akan semakin tinggi. Perbedaan ukuran skor kondisi tubuh diduga disebabkan oleh faktor genetik, faktor lingkungan dan juga faktor pakan. Sugeng (2003) menyatakan bahwa adanya perbedaan ukuran tubuh suatu ternak dipengaruhi oleh adanya beberapa faktor di antaranya faktor pengaruh bangsa sapi, pengaruh umur sapi, pengaruh jenis kelamin sapi, pengaruh pakan yang diberikan pada ternak sapi, pengaruh suhu serta iklim lingkungan di sekitar habitat sapi. Hal yang sama juga disampaikan oleh Sumantri (2007) selain faktor genetik, ukuran-ukuran tubuh dapat dipengaruhi oleh manajemen pemeliharaan di setiap lokasi pemeliharaan yang berbeda-beda.

\section{Simpulan}

Sapi Bali yang dipotong pada bobot potong150-199 kg rata-rata 177,86 $\mathrm{kg}$, memiliki berat karkas sebesar 78,76 kg, persentase karkas sebesar 44,28\%, berat non karkas dengan nilai rata-rata 99,10 dan persentase non karkas dengan nilai rata-rata $55,71 \%$. Korelasi bobot potong dan bobot karkas memiliki hubungan yang signifikan sebesar $0,527(0,000)$; berat non karkas adalah 0,088 $(0,580)$; persentase karkas $0,327(0,034)$; dan persentase non karkas 0,204 $(0,194)$.

Sapi Bali yang dipotong pada bobot potong 200-250 kg rata-rata 226,29, berat karkas $115,10 \mathrm{~kg}$, memiliki presentasi karkas $50,86 \%$, berat non karkas rata-rata $111,19 \mathrm{~kg}$, persentase non karkas rata-rata $49,13 \%$. Korelasi bobot potong Sapi Bali betina rata-rata berat $200-250 \mathrm{~kg}$ terhadap variabel pengukuran menunjukkan sebaran angka korelasi yang positif yakni: untuk berat karkas adalah $0,527(0,000)$; berat non karkas adalah $0,088(0,580)$; persentase karkas sebanyak 0,327 $(0,034)$; dan persentase non karkas sebanyak 0,204 $(0,194)$. Semakin tinggi bobot potong Sapi Bali semakin meningkat pula produksi karkasnya.

\section{Pustaka}

Badan Pusat Statistik 2016. Data Ekonomi dan Perdagangan dan Impor. Jakarta (Indonesia): Badan Pusat Statistik

Carvalho. 2010. Pertumbuhan dan Produksi Karkas Sapi Peranakan Ongol dan Simental-Peranakan Ongol Jantan yang Dipelihara Secara Feedlot. Buletin Peranakan. 34:38-36.

Hafid, H. 2005. Kajian Pertumbuhan dan Distribusi Daging Serta Estimasi Produktivitas Karkas Sapi Hasil Penggemukan. Disertasi. Bogor: Program Pasca Sarjana, Institut Pertanian Bogor

Imamul, A, Gina, HW. 2007. Membuka Cakrawala Ekonomi. Bandung: PT. Setia Purna Inves.

Ismail M., H Nuraini \& R. Priyanto. 2014. Perlemakan Pada SAPI Bali dan Sapi Madura Meningkatkan Bobot Komponen Karkas dan Menurunkan Persentase Komponen Non Karkas. Jurnal Veteriner 15(3): 411-421.

Lestari, C. M. S., Hudoyo Y, Dartosukarno S. 2010. Proporsi Karkas dan Komponen-Komponen Non Karkas Sapi Jawa di Rumah Potong Hewan Swasta Kecamatan Ketanggungan Kabupaten Brebes. Di dalam: Prosiding Seminar Nasional Teknologi Peternakan dan Veteriner Tahun 2010. Bogor, 3-4 Agustus 2010.

Manurung, L. 2008. Analisis Ekonomi Uji Ransum Berbasis Pelepah Daun Sawit, Lumpur Sawit dan Jerami Padi Fermentasi dengan Phanerochate Chysosporium Pada Sapi Peranakan Ongole. Medan: Departemen Peternakan Fakultas Pertanian Universitas Sumatra Utara.

Ninu, A.Y. 2008. Produktivitas Karkas dan Mutu Daging Sapi Bali Di Timor Barat Nusa Tenggara Timur. Tesis. Bogor: Institut Pertanian Bogor.

Padang dan Irmawati. 2007. Influence of Sex and Duration in Feeding to Carcass Weight and Percentage of Local Goat. J. Agrisistem. 3:13-20

Pradana, W., Mas Djoko Rudyanto, I Ketut Suad. 2014. Hubungan Umur, Bobot dan Karkas Sapi Bali Betina yang Dipotong Di Rumah Potong Hewan Temesi. Medicus Veterinus 37-42.

Pratama,. Agung Gilang, Siti Nurachma dan Andiana Sarwestri. 2015. Hubungan Antara Bobot Potong Dengan Yield Grade Domba (Ovis Aries) Garut Jantan Yearling. Fakultas Peternakan Universitas Padjadjaran.

Samariyanto. 2004. Alternatif Kebijakan Perbibitan Sapi Potong Dalam Era Otonomi Daerah. Lokakarya Sapi Potong.

Sampurna, I.P, Suatha I.K. 2010. Pertumbuhan Alometri Dimensi Panjang dan Lingkar Tubuh Sapi Bali Jantan. Jurnal Veteriner. XI(1): 46-51.

Soeparno. 2005. Ilmu dan Tekhnologi Daging. Cetakan keempat. Yogyakarta: Gadjah Mada University Press.

Sugeng, B. Y. 2003. Sapi Potong. Penebar Swadaya, Jakarta
Sumantri. C, A Einstiana, JF Salamena dan I Inounu. 2007. Keragaan dan Hubungan Phylogenik Antar Domba Lokal di Indonesia Melalui Pendekatan Analisis Morfologi. JITV. 12(1):42-54.

Suswono. 2009. Pemotongan Sapi Lokal Produktif. Departemen Pertanian. Jakarta.

Sugiyono. 2000. Statistik untuk Penelitian (cetakan ke 3). Bandung: Alfabeta.

Wiyatna, M.F. 2007. Perbandingan Index Perdagingan Sapi-Sapi Indonesia (Sapi Bali, Madura, PO) dengan Sapi Australian Comercial Cross (ACC). JIT.7(1). 